\title{
Effects of Hyperbaric Environment on Human Brain Stem Function with Specific Reference to Auditory Brain Stem Responses
}

\author{
Shin-ichi WADA', Shigeaki MATSUOKA', Chitoshi KADOYA', \\ Akira YOKOTA' ${ }^{1}$ and Motohiko MOHRI ${ }^{2}$ \\ 'Department of Neurosurgery, School of Medicine, University of Occupational and \\ Environmental Health, Japan. Kitakyushu 807, Japan \\ 2Japan Marine Science Technology Center. Yokosuka 237, Japan
}

\begin{abstract}
Hyperbaric chamber dives at 31 ATA with helium-oxygen were performed at the Japan Marine Science and Technology Center in 1987. During simulated underwater experiments, auditory brain stem responses were recorded in 4 professional divers for assessment of brain stem function. All divers had no clinical symptoms at $150 \mathrm{~m}$ below sea level, and their ABRs also showed no significant changes. During the $150-250 \mathrm{~m}$ depth saturation dives, all divers complained of various symptoms such as euphoria, ataxia, joint pain, tremor and dyspnea, while, I-III and $I-V$ interpeak latencies on their ABRs increased with a tendency of recovery. Furthermore, the changes of both interpeak latency were independent of each other. These results indicate that transient dysfunction clinically or subclinically occurred at the processes between 150-300 m below sea level. Moreover, independent changes of I - III and $\mathrm{I}-\mathrm{V}$ interpeak latencies in this study may mean that the pathways reached to the generation sites of wave III and $\mathrm{V}$ were different.
\end{abstract}

Key words: hyperbaric environment, brain stem function, ABR.

(Received 16 May 1988)

\section{Introduction}

The short-latency auditory evoked potentials, commonly referred as auditory brain stem responses (ABRs), consist of 7 vertex-positive peaks within the first $10 \mathrm{msec}$ after stimulus onset (Jewett \& Williston, 1971; Leb \& Sohmer, 1972). The short latencies of the ABR peaks implicate origins in peripheral and brain stem portions of the auditory system.

Recently, the ABR has proven to be an effective clinical tool for assessing the integrity of brain stem function in clinical populations because of its insensitivity to state variables such as level of corisciousness (Amadeo \& Shagass, 1973; Zollner et al., 1977), variation in arousal (Picton \& Hillyard, 1974) and directed attention (Wood \& Hillyard, 1978).

On the other hand, it has been known that various hyperbaric environments of over 21 absolute atmosphere (ATA) cause high pressure nervous syndrome (HPNS) whose clinical signs are characterized by headache, nausea, tremor, ataxia, disturbance of attention, euphoria and joint pain. We had oppotunities to participate in experiments of deep dive 
in Japan Marine Sciençe Technology Center (JAMSTEG), and have already reported the effects of hyperbaric environment of electroencephalography (EEG) (Matsuoka et al., 1987). The aim of this study is to clarify the effects of a hyperbaric environment at the $300 \mathrm{~m}$ below sea level with helium-oxygen on the human brain stem function by using ABR as an objective tool for assessment of its function.

\section{Materials and Methods}

Four professional divers, ages 34,22, 21 and 24 years old, participated in the dives to $300 \mathrm{~m}$. All of them were examined in detail and were found to have no clinical disease including hearing before the experiment. The experiment in a hyperbaric environment was performed in a human diving simulator at JAMSTEC in 1987. The hyperbaric dive took place according to the schedule and environmental parameters shown in Fig. 1.

Brain electrical activity was recorded from silver-silver chloride disk electrodes affixed to the vertex $(\mathrm{Cz})$ and bilateral mastoids. Recordings were obtained from the vertex referred to as ipsi-lateral mastoid (Cz-Mi) with a gain of 200,000 and a bandpass of $100 \mathrm{~Hz}$ to $3 \mathrm{kHz}$ (6 dB down). The responses were analyzed for $10 \mathrm{msec}$ after stimulus onset, with a resolution of $20 \mu \mathrm{sec}$ per data point. Each trial consisted of 2,000 stimuli and at least 2 trials were obtained to confirm reproducibility of results. Stimuli consisted of alternating rarefaction and condensation clicks, and $100 \mu \mathrm{sec}$ duration monaurally delivered at $10 / \mathrm{sec}$ at an intensity of $80 \mathrm{~dB}$ normal hearing level (nHL) through a couple of TDH-39 headphones. The ABR data were stored on a disk for subsequent off-line analysis. Total compression time including twice one hour pressure holding time was 14 hours, and

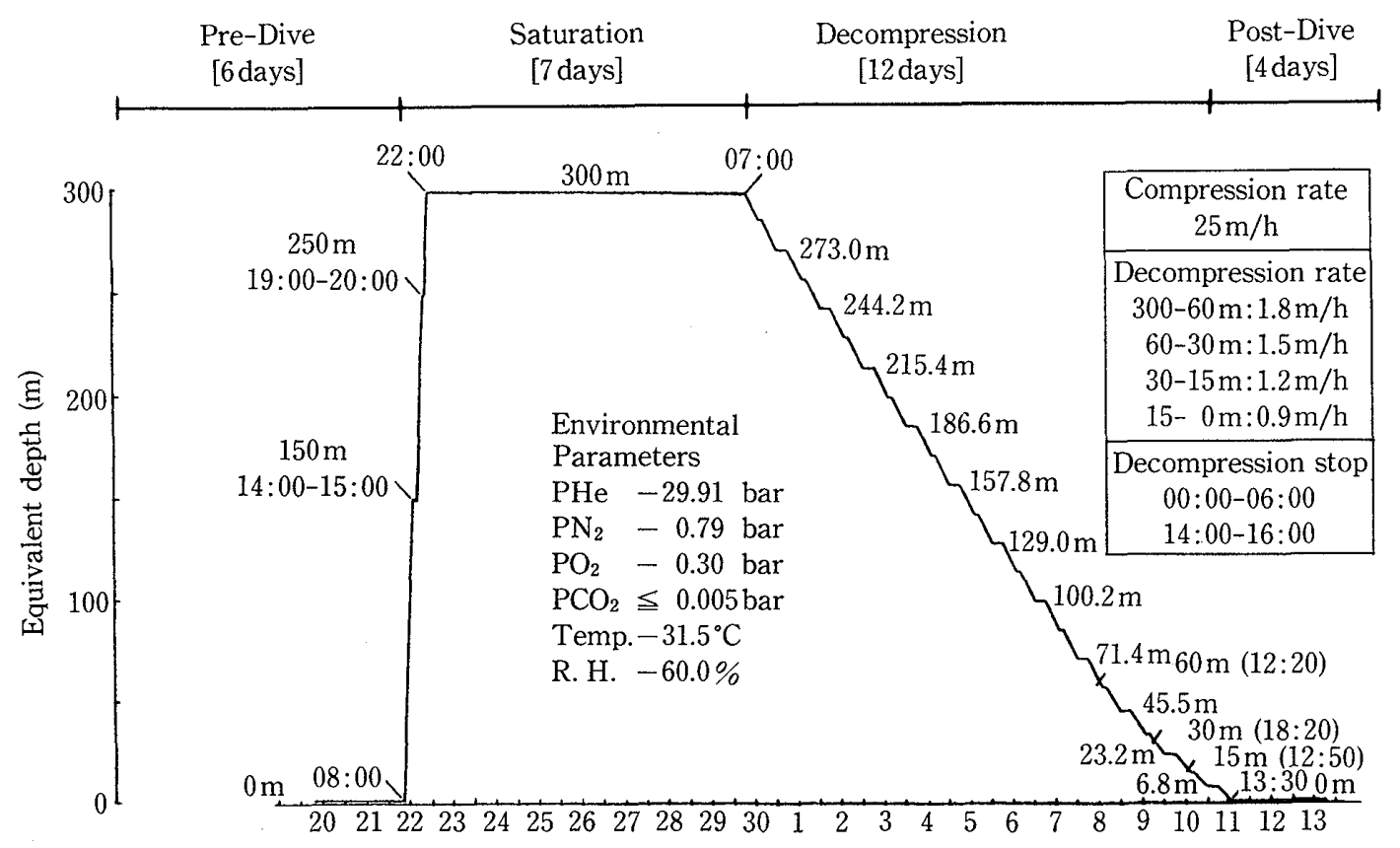

Fig. 1. Dive profile: During the compression, pressure holding time $(\mathrm{PH}=1$ hour $)$ was given twice at the 150 and $250 \mathrm{~m}$ below sea level. 
ABRs were recorded as 9 epochs in all divers during the compression period (compression rate $25 \mathrm{~m} / \mathrm{h}$; see Fig. 1). During the experiment the divers rectal temperature was monitored and their clinical symptoms were recorded in detail. From obtained data I - III and $\mathrm{I}-\mathrm{V}$ interpeak latencies, which are considered to mean mainly central conduction time of auditory pathway in the brain stem, were analyzed and compared with their symptoms, equivalent depth etc.

\section{Results}

Auditory brain stem responses of humans (Fig. 2), recorded between ' $\mathrm{Cz}$ ' electrode referenced to a mastoid electrode and stimulated by an ipsi-lateral ear, consist of 7 vertex positive waves in the first $10 \mathrm{msec}$ after stimulation. Five early components of them, which are considered to be generated by peripheral and brain stem portions in the auditory system, were designated by their polarity at the vertex ( $\mathrm{P}$ for positivity and $\mathrm{N}$ for negativity) and their approximate latency in msec. Moreover, wave I, II, III, IV and V were regarded as combining the peak to the follwing trough, i. e., P1-N1, P2-N2, P3-N3, P4-N4 and P5-N5 respectively (Wada et al. 1988).

Figure 3 shows the hyperbaric effects on $\mathrm{I}-\mathrm{III}$ and $\mathrm{I}-\mathrm{V}$ interpeak latencies, body temperature (rectal temperature) and clinical symptoms in each diver during the compression period. In all divers, both $I-I I I$ and $I-V$ interpeak latencies showed no significant effect due to the hyperbaric environment until $150 \mathrm{~m}$ below sea level as well as their clinical symptoms. At a hyperbaric environment of over $150 \mathrm{~m}$ below sea level the divers began to reveal various complaints such as joint pain, euphoria, tremor, ataxia and/or dyspnea. Of these symptoms joint pain, euphoria and ataxia occurred comparatively earlier than tremor and dyspnea. $I-I I$ and $I-V$ interpeak latencies were affected at a

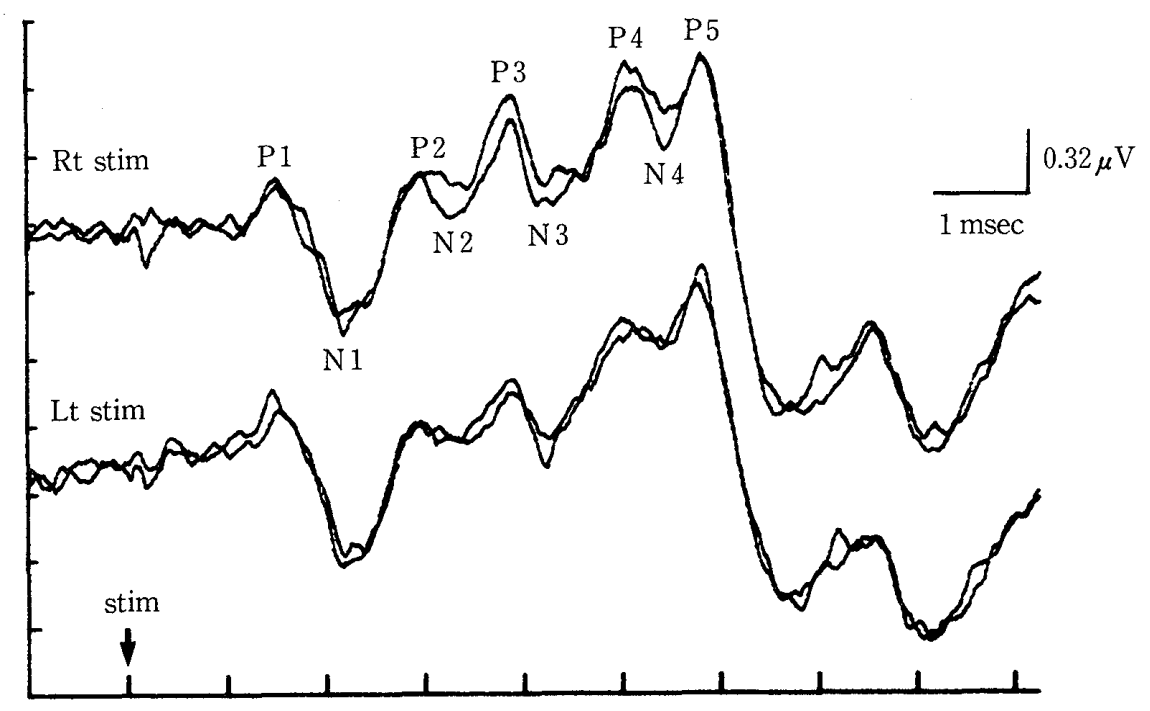

Fig. 2. ABRs in a normal adult subject to monaural stimulation. Wave I, II, III, IV and V were regraded as combining the peak to the following trough, i. e., P1-Ni, P2-N2, P3-N3, $\mathrm{P} 4-\mathrm{N} 4$ and P5-N5 respectively. 
hyperbaric environment corresponding to over $150 \mathrm{~m}$ below sea level with individual variation. The $\mathrm{I}-\mathrm{V}$ interpeak latency in 3 cases (Case YS, NM and F M) was prolongated between 150-250 m below sea level and showed a tendency to recover once, while the remaining case (YK) increased in latency only at the final stage of the compression period. On the other hand, I - III interpeak latency gradually increased from over $150 \mathrm{~m}$ below sea level with a tendency of recovery once, except for one case (YS) which continuously increased in $I-I I I$ interpeak latency. These $I-I I I$ and $I-V$ interpeak
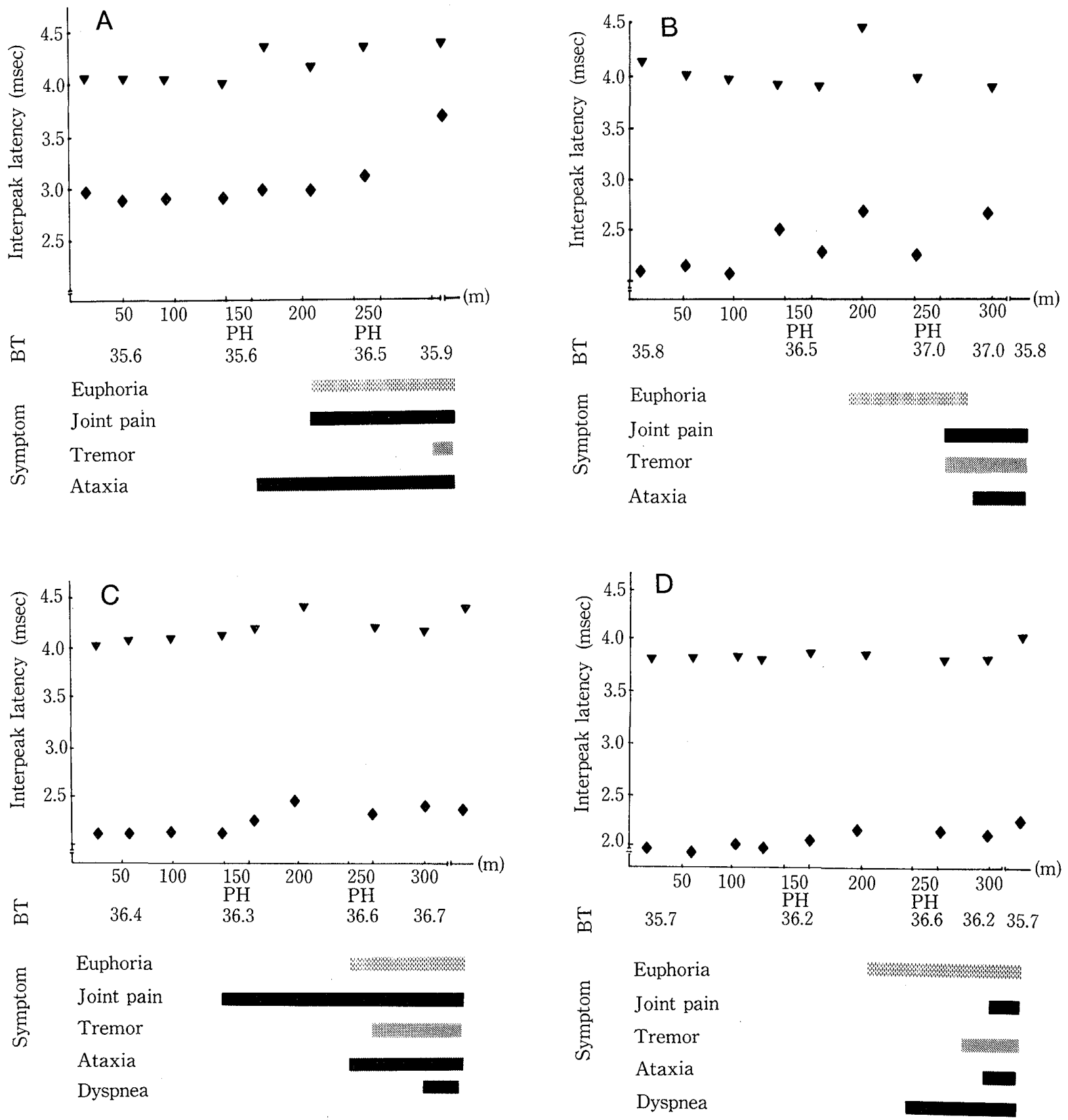

Fig. 3. Symptoms, body temperature (BT) and changes of $I-I I I(-)$ and $I-V(\boldsymbol{\nabla})$ interpeak latencies. A, case YS; B, case NM; C, case FM and D, case YK. 
latency changes were individually variable and there was no correlation between these interpeak latencies. Moreover, there was no correlation between these changes and body temperature.

\section{Discussion}

Saturation dives in a 31 ATA helium oxygen environment have been performed at the JAMSTEC since 1984 to insure human health and safety in similar operations at the bottom of the open sea at around $300 \mathrm{~m}$ which corresponds to the depth of the continental shelf in the neighboring sea of Japan. In addition, the detection of HPNS and its prevention have been an important problem for working safety at the bottom of the sea. On the other hand, there are many electronphysiological studies on such hyperbaric environments (Hock et al., 1986; Frost et al., 1970; Naquet et al., 1984; Thorn et al., 1986; Matsuoka et al. 1987). Therefore, this study was conducted to discover the hyperbaric effects on brain stem by using ABRs as one part of the research series. There has been little objective study about brain stem dysfunction caused by hyperbaric environment because of technical difficulty of ABR recordings under such a condition. Only $I-I I$ and $I-V$ interpeak latencies were employed in this study for assessment of the integrity of the brain stem function, because these interpeak latencies showed reliable reproducibility in comparison with the amplitudes.

The results in this study clearly indicated that the hyperbaric environment corresponding to up to $150 \mathrm{~m}$ below sea level caused an increase of $\mathrm{I}-\mathrm{III}$ and $\mathrm{I}-\mathrm{V}$ interpeak latencies on ABRs. According to recent studies about intra-subject, interscorer and intrascorer ABR reliabilities by Lasky et al. (1987), mean (SD) differences in msec by wave III and $V$ latencies by successive records (62 dB nHL, 20/sec) were 0.0217 and 0.0166 respectively in adult normal subjects, while the latency changes of these components in this study were much over their $2.5 \mathrm{~S}$. D. with little wave I latency changes. In addition to organic lesions of the brain stem, it has been well-known that some factors influence ABR latencies. Of these influencing factors, body temperature (Jones et al. 1977; Stockard \& Sharbrough, 1980; Achor \& Starr, 1980) and stimulus conditions(Starr \& Achor, 1975; Pratt \& Sohmer, 1976; Stephens \& Thornton, 1976; Huang \& Buchwald, 1978) were also important in this study. However, it is clear that changes of the body temperature were not a cause of the increasing of ABR components in this study because there was no correlation between them, e. g., increase in the interpeak latency in spite of rising temperature. The stimulus conditions were fixed during the experiments, but influence of $\mathrm{He}_{-} \mathrm{O}_{2}$ gas or pressure on the stimulus condition can not be overlooked. Both $\mathrm{He}-\mathrm{O}_{2}$ gas and pressure were applied at constant speed, and if $\mathrm{I}-\mathrm{III}$ or $\mathrm{I}-\mathrm{V}$ interpeak latency had been influenced by a changing sound stimulus caused by such gas or pressure, the latency changes must be linear (Wada \& Starr, 1983a). However, the increasing of interpeak latency in this study was transient and individual. Moreover, if the body temperature or stimulus condition influ- 


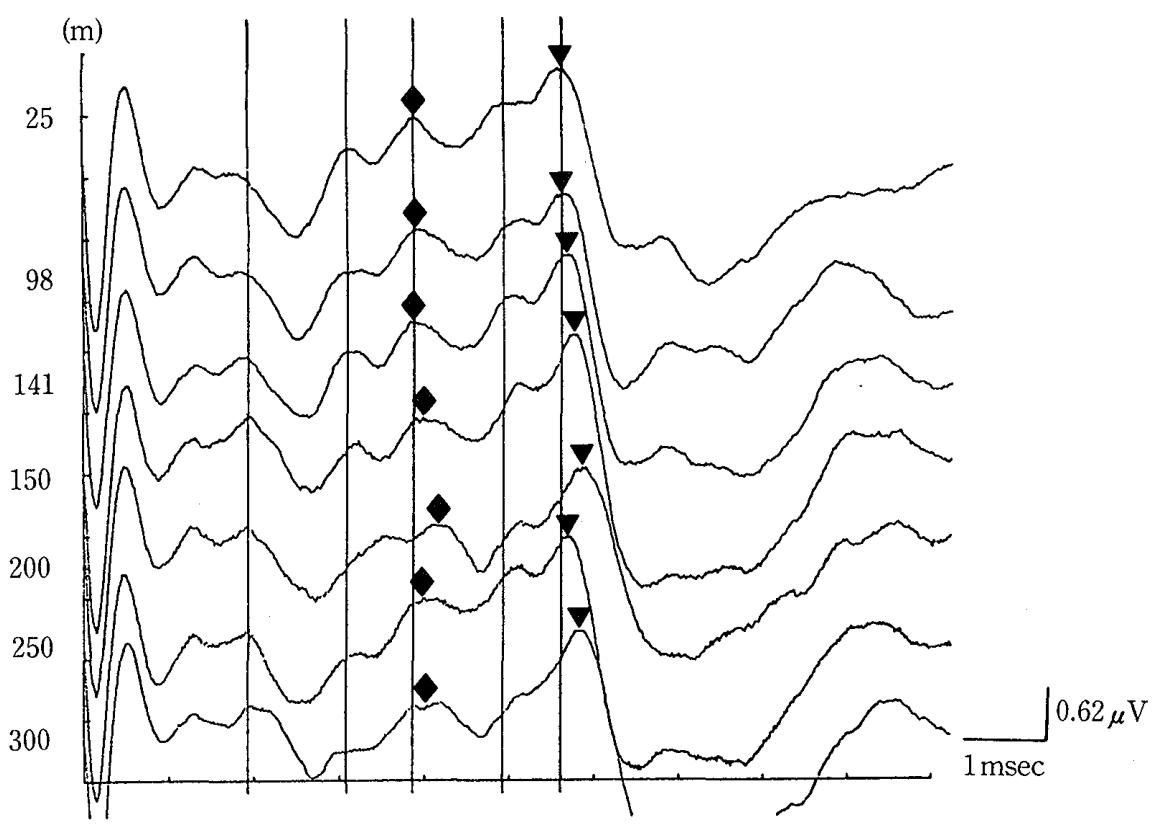

Fig. 4. $A B R$ changes during the compression period in case FM.

enced the ABRs, not only $\mathrm{I}-\mathrm{III}$ or $\mathrm{I}-\mathrm{V}$ interpeak latency but also wave $\mathrm{I}$ latency should have changed. However, wave I was always stable as shown in Fig. 4. That is, the increasing of the interpeak latencies in this study means that some brain stem dysfunction occurred at the hyperbaric environments. According to these results the brain stem dysfunction produced by hyperbaric environment corresponding to $300 \mathrm{~m}$ below sea level was probably transient because of the recovery of the increased interpeak latency. Moreover, it is an interesting result that $I-I I I$ and $I-V$ interpeak latencies were individually influenced. These results may mean that stimuli passes through separate pathways from the cochlear nucleus to the generation sites of waves III and $V$ in human ABR. These different pathways to generation sites of wave III and $\mathrm{V}$ in animals have been already reported (Buchwald, 1983; Wada \& Starr, 1983b).

\section{References}

Achor, L. J., \& Starr, A. (1980): Auditory brain stem responses in the cat. I Intracranial and extracranial recordings. Electroencephalogr. Clin. Neurophysiol., 48: 154-173.

Amadeo, M. \& Shagass, C. (1973): Brief latency click-evoked potentials during sleep in man. Psychophysiology, 10: 244-250.

Buchwald, J. S. (1983): Generators. In: Bases of Auditory Brain-Stem Evoked Responses. (Moore, E. J., ed.). Grune \& Stratton, New York. pp. 157-195.

Frost JR., J. D., Kellaway, P. \& DeLucchi, M. R. (1970): Evaluation of an automatic EEG acquisition and data analysis system-results during Tektite 1. In: Report on Project Tektite 1. (Pauri, D. D. \& Cole, H. A., ed.). ONR Report DR 153. Office of Naval Research, Washington, D. G.

Hock, R. J., Bond, G. F. \& Mazzone, W. F. (1966): Physiological evaluation of Sealab II . Effect of two weeks exposure to an undersea 7 atmosphere helium-oxygen environment Deep Submergence system 
project, U. S. Navy. Northrop Space Labs, Howthorne December. pp. 16-18, 41-44.

Huang, C. M. \& Buchwald, J. S. (1978): Factors that affect the amplitude and latences of the vertex short latency acoustic responses in the cat. Electroencephalogr. Clin. Neurophysiol., 44: 179-186.

Jewett, D. L. \& Williston, J. S. (1971): Auditory-evoked far fields averaged from scalp of humans. Brain, 94: $681-696$.

Jones, T. A., Siu, G., Stockard, J. J. et al. (1977): Effects of local systemic cooling on brainstem auditory responses. Electroencephalogr. Clin. Neurophysiol., 43: 469-470.

Lasky, R. E., Rupert, A. \& Waller, M. (1987): Reproducibility of auditory brain-stem evoked responses as a function of the stimulus, scorer and subject. Electroencephalogr. Clin. Neurophysiol., 68: 45-57.

Leb, A. \& Sohmer, H. (1972): Sources of averaged neural responses recorded in animal and human subjects during cochlear audiometry (electro-cochleography). Arch. Ohr. Nas. Kehlk. Heilk., 201: 79-90.

Matsuoka, S., Okuda, S., Wada, S.et al. (1987): Topographic characteristics of EEG during a saturation dive to 31 ATA helium-oxygen environment. Clinical Electroencephalogr., 27: 584-593. (in Japanese)

Naquet, R., Lemaire, G. \& Rostain, J. C. (1984): High pressure nervous syndrome; psychometric and clinico-electrophysiological correlations. Philos. Trans. R. Soc. Lond., B., 304: 95-102.

Picton, T. W. \& Hillyard, S. A. (1974): Human auditory evoked potentials. II . Effects of attention. Electroencephalogr. Glin. Neurophysiol., 36: 191-200.

Partt, H. \& Sohmer, H. (1976): Intensity and rate functions of cochlear and brainsiem evoked responses to click stimuli in man. Arch. Oto-Rhino-Laryngol., 212: 85-92.

Starr, A. \& Achor, K. J. (1975): Auditory brainstem responses in neurological disease. Arch. Neurol., 32: $761-768$.

Stephens, S. D. G. \& Thornton, A. R. D. (1976): Subjective and electrophysiologic tests in brain-stem lesions. Arch. Otolaryngol., 102: 608-613.

Stockard, J. J. \& Sharbrough, F. W. (1980): Unique contributions of short-latency auditory and somatosensory evoked potentials to neurologic diagnosis, In: Progress in Clinical Neurophysiology, Vol 7. (Desmedt, J., ed.). S. Karger, Basel. p. 231.

Thorn, T., Whidden, S. J., Gottlieb, S. F. et al. (1986): Evaluation of the human normative monaural averaged brainstem auditory evoked responses in the hyperbaric 6 ATA air environment to surface control. Proceeding of 9th Int. Symposium on Underwater and Hyperbaric Physiology, Kobe. p. 39.

Wada, S. \& Starr, A. (1983a): Generation of auditory brain stem responses (ABRs). I . Effects of injection of a local anesthetic (procaine HCl) into the trapezoid body of guinea pigs and cat. Electroencephalogr. Clin. Neurophysiol., 53: 326-339.

Wada, S. \& Starr, A. (1983b): Generations of auditory brain stem responses (ABRs). III. Effects of lesions of the superior olive, lateral lemniscus and inferior colliculus on the ABR in guinea pig. Electroencephalogr. Clin. Neurophysiol., 56: 352-366.

Wada, S., Matsuoka, S., Urasaki, E. et al. (1988): Quantitative analysis of reversible dysfunction of brainstem midline structures caused by disturbance of basilar artery blood flow with the auditory brain-stem responses. Electroencephalogr. Clin. Neurophysiol., 69: 148-159.

Wood, D. \& Hillyard, S. (1978): Attention and the cocktail party: brainstem responses reveal no peripheral gating. In: Multidisciplinary Perspectives in Event-Related Brain Potential Research. (Otto, D., ed.). U. S. Government Printing Office, Washington DC. pp. 230-233.

Zollner, C., Karnahl, T. \& Stange, G. (1977): Does prometazine (Atosil) influence the human's early acoustically evoked potentials in the same way as the late potential Nl? Arch. Oto-Rhino-Laryngol., 215: $231-240$. 
高圧環境下における聴性脳幹反応を用いた脳幹機能の評価

和田 伸- ${ }^{1} \cdot$ 松岡 成明 $^{1} \cdot$ 角谷千登士 ${ }^{1}$ 横田 晃 $^{1} \cdot$ 毛利 元彦 $^{2}$

1産業医科大学脳神経外科学教室 2海洋科学技術センター

要 旨： 大陸棚開発に必要な水媣 $300 \mathrm{~m}$ での海中作業技術の確立と安全を目的とした海洋技術セ ンターでの潜水シェミレーターを用いて実施された実験に参加し, 加圧経過中, 聴性脳幹 反応 $(\mathrm{ABR})$ を 4 人の被験者（プロダイバー）に記録する機会を得た. 被験者は全員水深 $150 \mathrm{~m}$ までは何ら異常を示さず, ABR も変化なかったが, 水深 150-250 m で関節痛, 多幸, 振戦, 運動失調, 呼吸困難等を次々と訴え, ABR の I-III, I-V 頂点間潜時も 有意に延長した。この頂点間潜時の延長は水深 $300 \mathrm{~m}$ までに一旦回復する傾向がみられ た。また,これらの ABR の変化は体温変動と相関性はなく, 刺激条件等の影響も考えら れず, $\mathrm{He}-\mathrm{O}_{2}$ ガスの加圧による脳幹機能の一過性の機能低下によるものと考えられた.さら に，I－III，I－V 頂点間潜時は互いに独立しており，このことは ABRの III 波, V波の 発生源へ達する刺激が独立した別々の伝導路を通る可能性を示唆する所見と考えられた。

J. UOEH (産業医大誌), 10 ( 3 ): 317-324 (1988) 